\title{
ヴイタミンA.コレステロール.脂油類及其 他の物質に對する紫外光線の作用に就て
}

(大正十四年七月一日受理)

\section{農學士濱 野 貞 行}

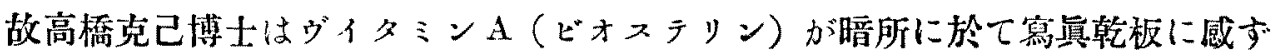
るの性質あるを發見し同氏及著者は之に紫外光線を働かしされば其作用一層强大 そなる事を實驗し更にコレステロール、肝油、オリーブ油等に就て試驗せるにウ イタミンA以外のものは其價にては其作用非常に微弱なるも之に紫外光線を働か

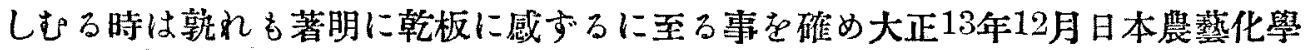
會の例會に於て其成績の一端芭發表したり、然るに其後幾何ならすして高橋博士 は不幸長逝せられたるを以て著者は本砳究夿繼承する事さなれり、本斫究は僅に 其端緒を開きたるに過ぎざるも鬼に角今日迄に得たる結果を報告せんこ欲す

近桃紫外光線が動物榮養及成長に關係あるを唱ふるもの多く殊に佝侥病に對し てはヴイタミン $\mathrm{A}$ こ同樣の效果あるを報告せるものあり更に最近 ${ }^{(1)}$ ステーンボッ

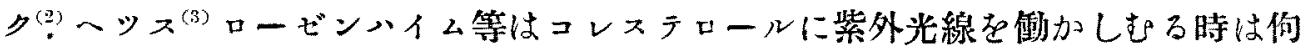

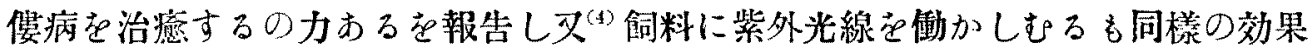

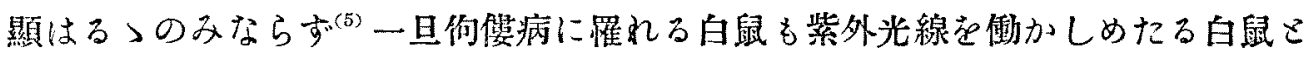
同居せしむれば之が治癒するに至る事を報告せり、若し此等の賽驗にして誤なし こせば如何にして之を說明すべきか

高橋博士は既にビオステリン特有の効力は寫直乾板に威する力の强弱に比例す る事を指摘し肝油或はビオステリンを酸化せしさるか或は他の操作に依りて効力 を失はしぬたるものは同時に乾板に感ずるの性質が甚げしく消失する事を報告せ

(1) Steenbock and Daniels (1925) J. An. med. Ass, No. 15 vol. 841093.

(2) Hess and Weinstcck (1925) J. Biol. chem, 63. 305.

(3) Rosenheim and Webster (1925) Lancet. No. XX rol, I 1025.

(4) Steenbock and Black (1925) 61, 405 .

(5) Nelson and Steenbock (1925) 62. 575. 
り、故に氏はビオスチリンが常に一種の極めて不安定なる物質を放散しつ〉ある か或は周圍の空氯を活性ならしめて乾板に感ずにに至るものならんこ想像せり、 今若しコレステロール、脂油等が紫外光線の作用に㑈りて何嫫病を治瘺するの性

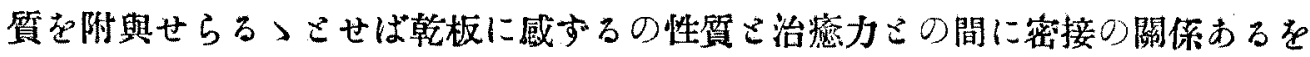
想像するに難からず、恐らくは一時的に極めて不安定なる Atougruppe 觉生ずる か或はペルォキシードの如きものきならて周園の空氮を活性ならしる事あるべし、 是今後研究す心゙き興咮ある問題なりこす

今著者は其說明を後に讓り單に筫瞼上の事實のみを記述して參考に供せんこ 欲市

\section{賽 驗之 部}

紫外光線を發生せしむるには長岡博士の御好意に上り最近同博士力洘案せられ たる常壓水銀燈学用ひたり本裝置は第入圖に示す如く透明なっ石英管をU字形に 屈曲し之に水銀光光し Bogen の部分法他よりす稍細く此部分を Reservoir この間

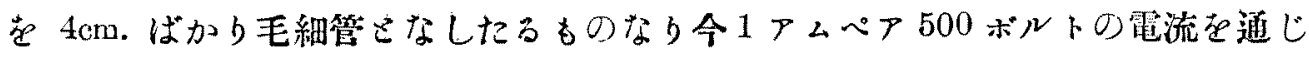
Bogen の部分を泩意して熟する時は此所に水銀の蒸氮它生し紫外光線を發するに 至る Bogen の長さは $4 \mathrm{~cm}$.にして長時間連續使用に堪ゆるものなり

今特に泩意して精製せるコレステロールを石英試驗管（長さ $15 \mathrm{~cm}$. 外經 $1 \mathrm{~cm}$. ) に入れゴム栓を施しデコチンスキーセメントを以て密封し上記水銀登の光孤の下 に $10 \mathrm{~cm}$. の距膗に於て 24 時間作用せしめたる後其 $1 \mathrm{~g}$. 取りて結晶血（外經約 $3 \mathrm{~cm}$. 高さ $1.6 \mathrm{~cm}$.) に入れ其上を乾板 (Lion Express Ortho)にて蔽ひ結晶こ乾板さ の距離を約 $1 \mathrm{~cm}$. こし紙箱に入れて24時間暗室に放置したる後普通の如く現像す ろ時恃乾板の結晶血を蔽ひたる部分のみ著しく黑色こなるも紫外光線を作用せし めずして全然同一の操作を秝りたるコンスラロールは全く乾板に感せず、斯の如 くして多數の實驗を繰り返へしたるが其結果を概括すれば炏の如し

（1）コレステロール、肝油、オリーブ油、オンイン酸及其石灰監、桂皮酸、 アビェチン酸樟、腦龍、腦薄、荷腦、バルサム類等は就れも紫外光線に作用せし むる事に佊りて强く乾板に感ずるる之に作用せしめざる時は威ずる事弱きか或は 殆す威ず事なし（第 $1-4$ 圖）

（2）石英試驗管中にコレスラロールを入れ之に水素を光したるるの或は之を 且空さなしたるものよりる之に空氣を充したるものは乾板に感する事著しく强し 
(第五圖)、之に酸素を充したるものは更に强し、而して試驗管中の濕埭の有然は 左程關係な゙が如し

（3）一旦紫外光線に作用せしめたるコレスラロールを暗所に放置すれば潮次

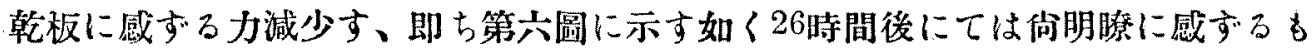
98時間後にては殆んぎ威せざるに至る

（4）同一の供試料を石英試驗管及硝子試驗管に入れて前記の如く紫外光線を 㗢加しめ其各 1g. 在取りて前記の如く處理するに硙子は紫外光線を吸收するもの なるに拘はら柰第七圖に見る如く佾輕度に感せら、故に普通の紫外線以外に此作 用を呈するものあるに非ざるかを疑はしむ、只此試驗に用ひたる硝子管が幾何の 波長迄它四收するかは疑問なり

（5）葡萄榶、蕉糖、澱粉、飽和脂肪酸、エライデン酸、琥珀酸、コルク酸、アミノ 酸、サッチール酸、アントラセン、ナフタリン、セチールアルコール等は紫外線さ 㗢かしさるも乾板に感ずる事なし

終に蜼み此貿驗に對し御便宜を圖られたる長岡年太郎博士、理學士淺田常三郎 君及町田敏男君の御好意を謝し終始御指導を給はりたる恩師鈴木梅太郎先生に愿 く感謝の意を表す 
Abb. 1 Cholesterin

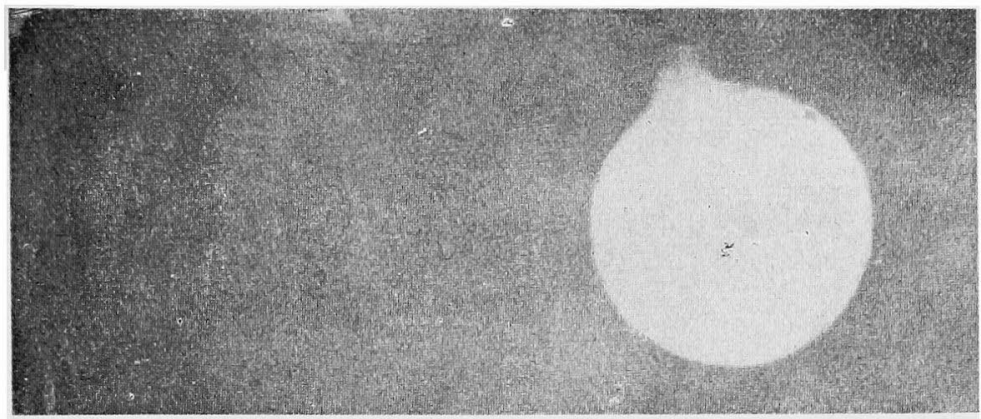

nicht bestrahlt

bestrahlt

Abb. 2 Butter

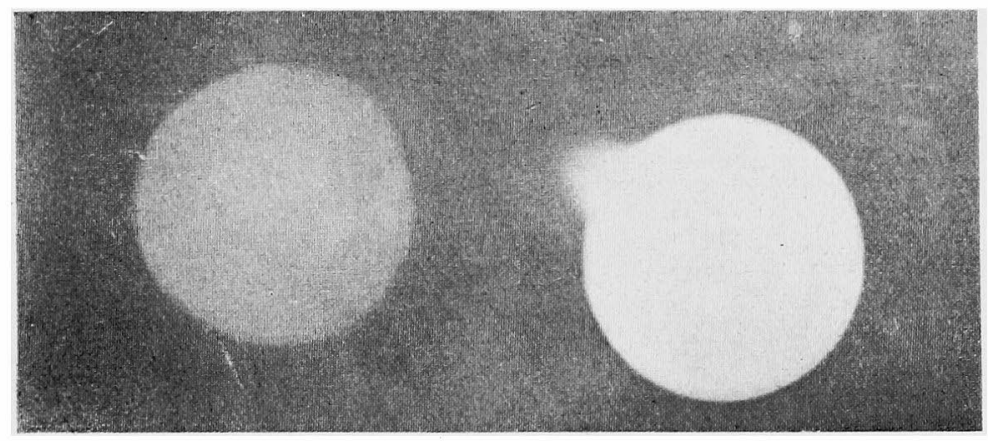

nicht bestrahlt

bestrahlt

Abb. 3 Lebertran

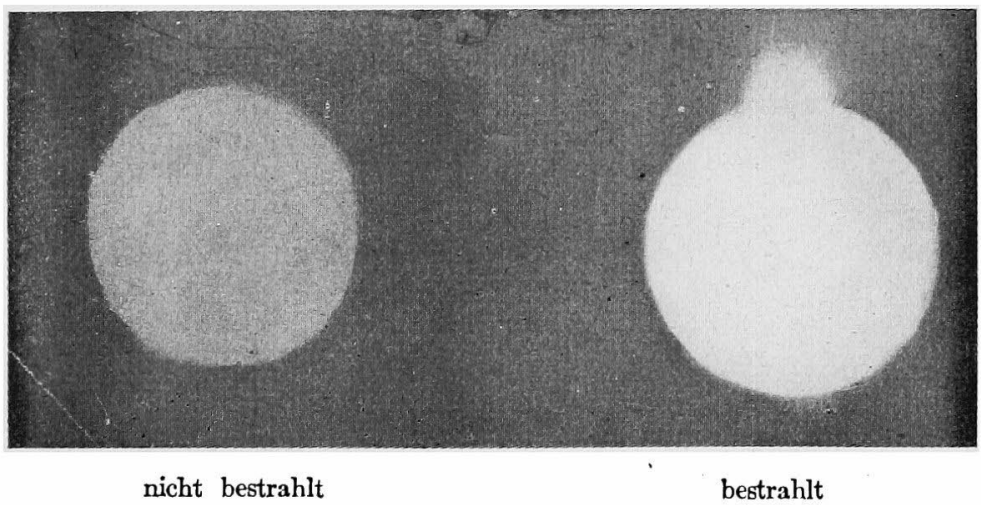


Abb. 4 Olivenöl

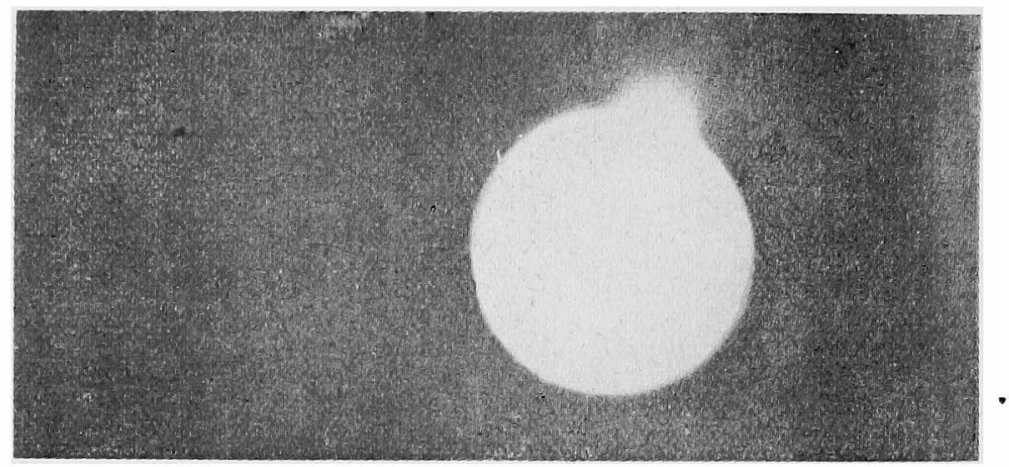

nicht bestrahlt bestrahlt

Abb. 5 Cholesterin

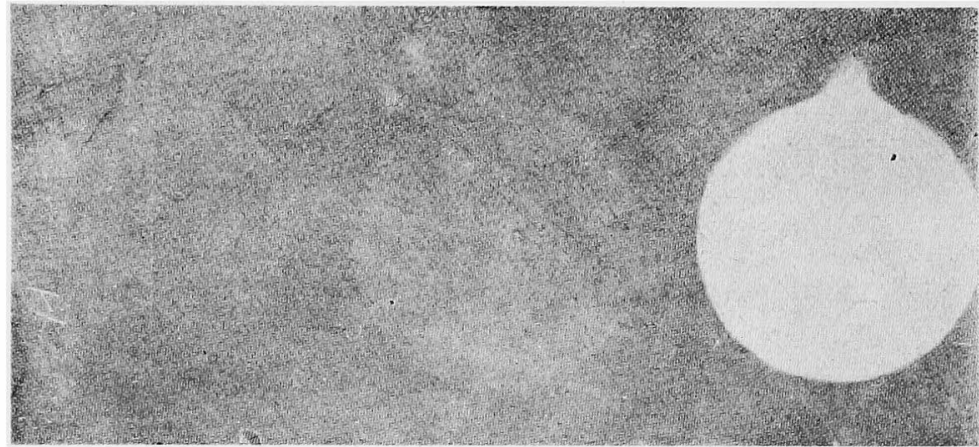

in Wasserstoff

in Vakuum

in Luft

Abb. 6. Cholesterin

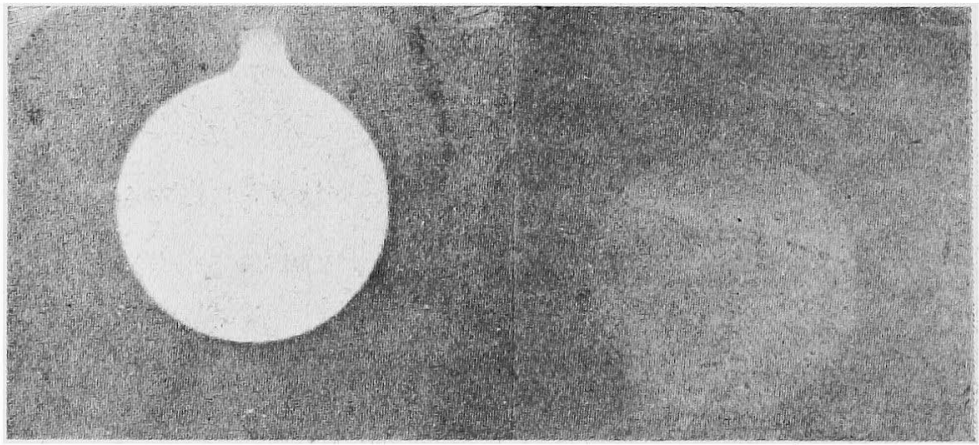

26 Stunden nach

Bestrahlung
98 Stunden nach

Bestrahlung 
Abb. 7 Cholesterin

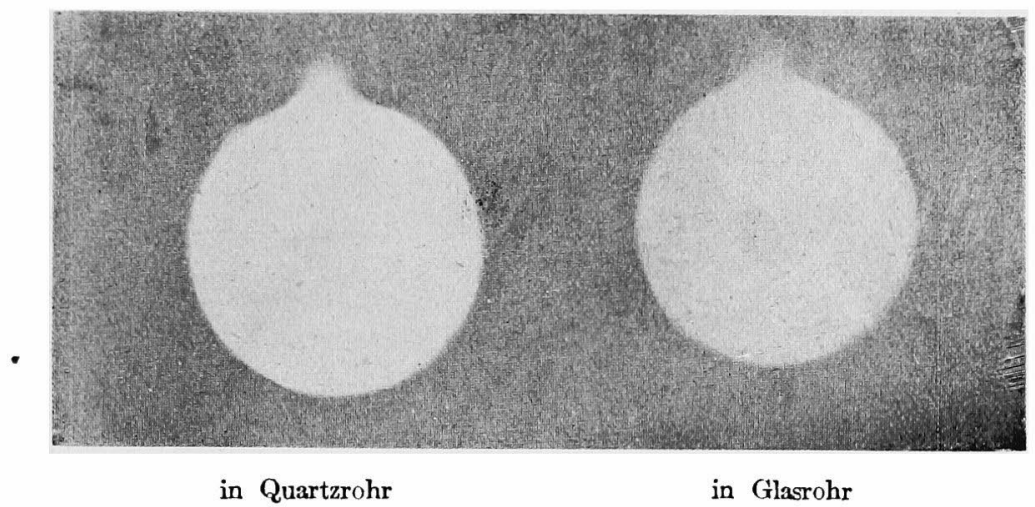

Abb. 8 Quecksilberlampe nach Prof Nagaoka.

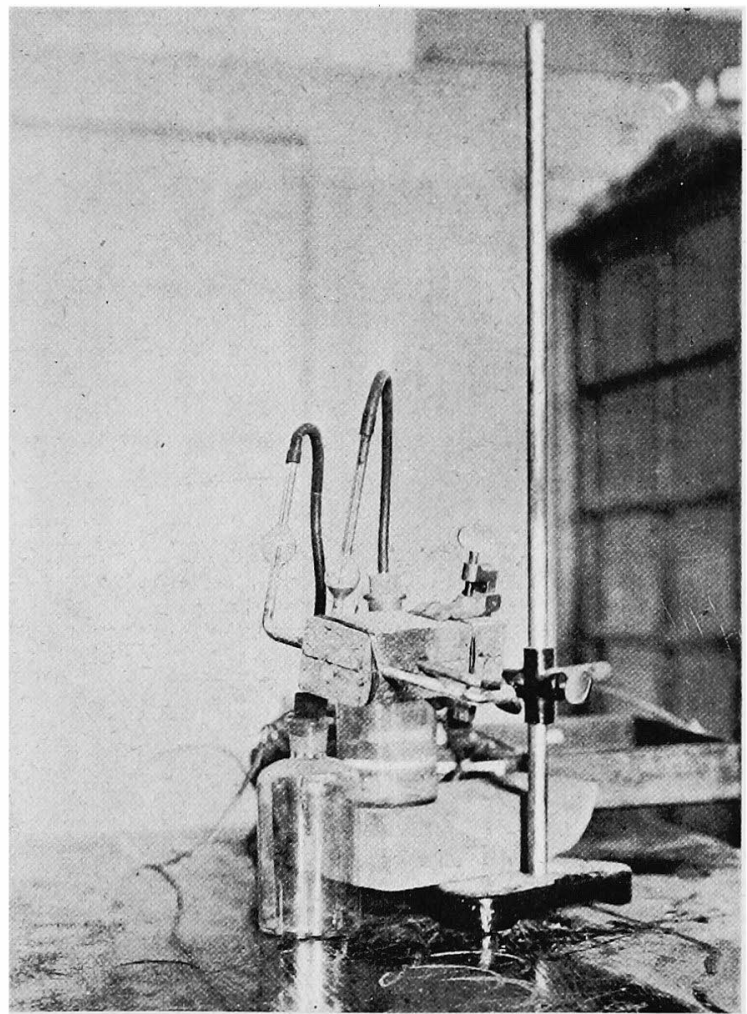

